\title{
Evaluation of bitter gourd varieties on different methods of cultivation
}

\author{
Abdullah Khan ${ }^{1}$, Quaid Hussain ${ }^{2 *}$, Muhammad Asim³ ${ }^{3}$ Nangial Khan ${ }^{4}$, \\ Habibullah $^{5}$, Rafeh Ullah ${ }^{1}$, Murad Ali ${ }^{1}$, Mahnoor Khan ${ }^{6}$, Altaf Hussain ${ }^{1}$ \\ and Ahmad Naeem ${ }^{1}$ \\ 1. Department of Horticulture, The University of Agriculture, Peshawar, Pakistan \\ 2. State Key Laboratory of Subtropical Silviculture, Zhejiang A\&F University, 666 Wusu Street, Hangzhou 311300, \\ China \\ 3. Tobacco Research Institute, Chinese Academy of Agricultural Sciences, China \\ 4. Department of Agronomy, The University of Agriculture, Peshawar, Pakistan \\ 5. North East forestry university Harbin, China \\ 6. Department of Botany, Women University Swabi, Pakistan \\ *Corresponding author's email: quaid_hussain@yahoo.com \\ Citation \\ Abdullah Khan, Quaid Hussain, Muhammad Asim, Nangial Khan, Habibullah, Rafeh Ullah, Murad Ali, Mahnoor \\ Khan, Altaf Hussain and Ahmad Naeem. Evaluation of bitter gourd varieties on different methods of cultivation. Pure \\ and Applied Biology. Vol. 11, Issue 1, pp58-71. http://dx.doi.org/10.19045/bspab.2022.110007 \\ \begin{tabular}{llll}
\hline \hline Received: 00/02/2021 & Revised: 00/04/2021 & Accepted: 00/05/2021 & Online First: 17/05/2021 \\
\hline \hline
\end{tabular}
}

\section{Abstract}

An experiment on evaluating bitter gourd varieties on different cultivation methods was conducted at the Agriculture Research Institute Tarnab Peshawar, Pakistan, in 2016. The experimental plots were arranged in Randomized Complete Block Design (RCBD) with split plot arrangement. Layout methods were considered the main plots, and varieties were allotted to subplots. Different varieties of Bitter gourd Kiran, Jaunpuri, and Peshawar Local were trailed on various layout ways, i.e., Vertical on net trailing method and conventional on the ground trailing method. Results showed significant variations among different layout methods. Vertically on net trailing method took minimum (39) days to flower, while maximum fruit length $(17.44 \mathrm{~cm})$, vine length $(4.32 \mathrm{~m})$, fruit diameter $(4.82 \mathrm{~cm})$, fruit weight $(67.25 \mathrm{~g})$ yield plot $^{-1}(12.27 \mathrm{~kg})$, fruit yield $\left(13.63 \mathrm{t} \mathrm{ha}^{-1}\right)$, and the net return in the cost-benefit ratio was (7.69) rupees. Kiran variety produced significantly more number of fruits vine ${ }^{-1}(17.6)$, individual fruit weight $(68.02 \mathrm{~g})$, fruit length $(19.18 \mathrm{~cm})$, vine length $(4.45 \mathrm{~m})$, number of branches vine ${ }^{-1}(10.03)$ while yield plot ${ }^{-1}$ were $(12.01 \mathrm{~kg})$ and fruit yield (13.34 $\mathrm{t} \mathrm{ha}^{-1}$ ). The interaction among the layout methods and varieties showed that less number (38) of days were taken to flowering by the Kiran variety, maximum vine length $(4.46 \mathrm{~m})$, number of branches vine ${ }^{-1}(10.03)$, and fruit yield $\left(15.51 \mathrm{t} \mathrm{ha}^{-1}\right)$ when trained vertically on the net. From these findings, it is observed that the vertical trailing method on net and Kiran variety is prominent both in production and quality.

Keywords: Bitter Gourd; Conventional; Varieties; Vertical,; Yield

\section{Introduction}

Bitter gourd (Momordica charantia L) belongs to the family Cucurbitaceae and is regarded as an essential home gardening vegetable. Almost sixty species of the genus Momordica includes chrantia and cochinchinensis. Tropical Asia is believed to be its origin, where it is widely spread in 
Pakistan, China, India, Bangladesh, Malaysia, and tropical Africa [1]. Usually, bitter gourd is 3 to 4-meter-long with a climbing capacity and is an annual slender stem, and the leaves are found on long-stalk with 5 to 9 palmate lobed structures. Male and female flowers are produced on the main stem with a diameter of $2-3 \mathrm{~cm}$.

The male flowers have a distinguishing yellow center with a conical base, while the female flowers have a small bump at the base and a green center. Monoecious flowers are borne in the axils leaf alone, with calyx having five sepals and yellow petals, three stigmas, and stamens each. However, the male flowers first appear, followed by female flowers, finally leading to whole fruit. The fruits are green pear-shaped or sometimes maybe oblong with 8-10 longitudinal irregular ridges. The young fruit's color is green, but the green color later turns orangeyellow on ripening [2]. The fertilized fruits of bitter gourd showed rapid growth in hightemperature areas. It takes 12 to 16 days to be harvested in warm conditions, and the fruits mature in 16 days after pollination. At lower temperatures, the fruits require more time (22 days) to be harvested and become yellow 24 days after pollination. Development of seed also occurred rapidly at high temperatures. Delayed development of the embryo, seed, and fruit was observed at low temperatures [3].

Layout methods are essential cultural practice for many horticultural crops and are mainly used for dense foliage crops that inhibit light penetration to the leaves underside. Dense leaves decrease plant's photosynthetic ability and increase humidity, enhancing the existence and spread of diseases that affect cucumber production and quality [4]. The vertical layout method improves photosynthesis activities, which play an essential role in increasing yield [5]. The abortive and small fruits cold be discarded by boiling them in salty water or rubbing them with salt. Bitter gourd has relatively high nutritional value regarding ascorbic acid and iron contents. A $100 \mathrm{~g}$ fruits sample comprises about $92 \mathrm{ml}$ of water, 0.2 $\mathrm{mg}$ of iron, $1.2 \mathrm{~g}$ of protein, and $0.07 \mathrm{mg}$ of riboflavin, and $20 \mathrm{~g}$ of thiamine. At the same time, $100 \mathrm{~g}$ of leaves obtained $80 \mathrm{ml}$ of water, $5.1 \mathrm{~g}$ of protein, $264 \mathrm{mg}$ of calcium, $12 \mathrm{~g}$ of carbohydrate, $0.5 \mathrm{~g}$ of fiber, $0.4 \mathrm{~g}$ of fat, 666 $\mathrm{mg}$ of phosphorus, $7.1 \mathrm{mg}$ of iron, $0.47 \mathrm{mg}$ of riboflavin and $0.05 \mathrm{mg}$ of thiamine [6]. Bitter gourd has a very high medicinal value, and its juice has many medical advantages and is mainly used for decreasing sugar in the blood $[7,8]$. For the treatment of many ulcers, infections, and diabetes diseases, Momordica charantia $\mathrm{L}$ is used.

Similarly, it is also used in folkloric medicine [9-11]. Its juices from the leaves and stems are used to treat rheumatism, dysentery, and gout [12]. The juices extracted from leaves, fruits, and even from the entire plant are used to treat many diseases [13]. The bitter guard's effective production method is direct seeding, but occasionally, seedlings are transplanted directly to the fields. The seed coat of bitter gourd is very hard, and its germination takes place very slow due to low water absorption. For early germination, the best temperature is in the range of 25 to 28 ${ }^{0} \mathrm{C}$. Treatments of seed such as seed soaking in a little hot water for 30 mints and stored at a warm place in a bag for about 3 to 4 days, these treatments enhance the germination speed [14]. Priming is another treatment used in mixing seeds with wet vermiculate for 36 hours at $20^{\circ} \mathrm{C}[15,16]$. It evaluated varieties of the bitter gourd and the growth parameters and yield of needing a favorable environment. It also ensures continuity of supply to processors and the fresh market. Several bitter gourd varieties are available, but old varieties; cultivation continuously loses quality and becomes susceptible to insects, pests, and diseases. 
In Pakistan, the bitter gourd cultivated under 6107 hectares with a yield of 56949 tons. In KPK, it cultivated an area of 749 hectares with a yield of 6859 tons [17]. Khyber Pakhtunkhwa has the most suitable climatic condition to produce bitter gourd, but the yield $\mathrm{ha}^{-1}$ is very low. Many factors are responsible for low yield, i.e., unavailability of the seed of improved varieties, inappropriate plant protection measures, poor nutrition and irrigation, and outdated field layout techniques. Two essential factors were considered to work on: improved field layout method and suitable selection. For this purpose, research was experimented with to investigate the sponge of bitter gourd varieties and various field layout ways in Peshawar agro-climatic conditions.

\section{Materials and Methods}

The research was conducted at the Agriculture Research Institute Tarnab Peshawar in 2016 to investigate the best layout method for the better growth, yield, and quality of bitter gourd. Two different layout methods (Vertical and Conventional) were applied to three different varieties (Kiran, Jaunpuri, and Peshawar local) of bitter gourd. In the vertical layout method, the vines were trained on supporting materials vertically so that the vines and fruit should not touch the ground; for this purpose, two-meter-long bamboo poles were erected with 3 meters' pole to pole space. The space between the poles was netted with strings to train the vines on that net. Moreover, in the conventional layout method, the vines were spread on the ground without any supporting materials.

The experiment is arranged in a split-plot arrangement on randomized complete block design. The total number of treatments was six, while each treatment was replicated three times. The trailing methods were kept in main plots, and varieties (Kiran, Jaunpuri, and Peshawar local) were assigned in subplots. Plant to plant distance was $30 \mathrm{~cm}$, and plot size was $3 \times 3 \mathrm{~m}\left(9 \mathrm{~m}^{2}\right)$. The seed was sown on ridge sides at a depth of $2-2.5 \mathrm{~cm}$. Before sowing compost, the manure was incorporated in the field at a rate of $50 \mathrm{t} \mathrm{ha}^{-1}$ [18].

Irrigation of the field was done after ten days during cold weather and weekly during the hot, dry season. During the rainy season, proper drainage was done, which is essential for the plant's life. All other cultural practices were applied to the need and situations.

The following parameters were studied.

\section{Time for germination}

Germination was recorded by counting the number of days from sowing to eighty percent of germination.

\section{Percent germination of seeds}

The germinated seeds were counted while percentages were calculated by using the following formula.

Seed germination rate $(\%)=\underline{\text { Seed }}$ germination Number $\times 100$

Total no of

seeds sown

\section{Branches numbers per vines}

Branches number per vines was counted by assessing the branch numbers at three randomly chosen in every treatment and mean had found.

Vine length (m)

The vine length was calculated in meter using tape, from the vine base to the tip, and means were calculated in each treatment.

\section{Days to early flowering}

The number of days to flowering was calculated from $50 \%$ of the days to start blooming.

\section{Length of fruits (cm)}

Fruit length $(\mathrm{cm})$ was measured by measuring tape. The mean was calculated by choosing three fruits and every treatment of replication.

\section{Fruit diameter $(\mathbf{c m})$}

Vernier caliper calculated the fruit diameter, and the fruits were chosen in every treatment 
of replication for fruit length and then calculated the average.

\section{Fruit weight (g)}

The fruit weight was noted by picking three fruits from every treatment, and then the average was calculated.

\section{Fruit numbers per vine}

By calculating fruit numbers per vine were picked in each treatment, then calculating the average, and collecting the data on the number of fruits vine ${ }^{-1}$.

\section{Fruit yield plot $^{-1}(\mathbf{k g})$}

Fruit yield plot $^{-1}$ was weighted of each picking, and treatment was recorded in kilogram, and then the average was calculated.

\section{Fruit yield (t ha' $\left.{ }^{-1}\right)$}

Fruits yield data were recorded on the weight data for each picking. Calculate the fruit yield for each treatment the last picking in $\left(\mathrm{t} \mathrm{ha}^{-1}\right)$.

\section{Cost-Benefit Ratio}

$$
\text { Yield* }\left(\mathrm{t} \mathrm{ha}^{-1}\right)=\frac{\text { Fruits yield* } \text { plot }^{-1}\left(\mathrm{~kg}^{*}\right) \times 10000 \mathrm{~m}^{2}}{\text { Plot area* }\left(\mathrm{m}^{2}\right)}
$$

Input cost for land preparation, fertilizer, seed cost, manure cost, and power required for all the operations to transplant seedling to the harvesting of bitter gourd was recorded for a unit of cost per hectare. Prices of bitter gourd were considered on the market-rate basis of the Peshawar market.

For the Soil analysis, the following (Table 1) was used.

Table 1. Soil analysis

\begin{tabular}{|l|l|l|}
\hline Property & Unit & Quantity \\
\hline Nitrogen (N) & $\mathrm{Mg} \mathrm{Kg}^{-1}$ & $0.025 \%$ \\
\hline Phosphorus (P) & $\mathrm{Mg} \mathrm{Kg}^{-1}$ & $4.2 \%$ \\
\hline Potash (K) & $\mathrm{Mg} \mathrm{Kg}^{-1}$ & $80 \%$ \\
\hline Soil Organic matter & $\%$ & $0.51 \%$ \\
\hline Soil pH & - & $8.0 \%$ \\
\hline Soil E.C & $\left(\mathrm{dsm}^{-1}\right)$ & $0.20 \%$ \\
\hline
\end{tabular}

\section{Statistical procedure}

The ANOVA technique was performed on the data recorded on the different parameters to find the difference between the different treatments and their interactions. In the case of significant discrepancies, the difference was compared using the least significant difference (LSD) test. Statistical computer software Statistix 8.1 is used to calculate ANOVA and LSD [19].

\section{Results and Discussion}

Bitter gourd varieties were evaluated on different cultivation methods in spring 2016 at the Agriculture Research Institute Tarnab, Peshawar. Data were recorded on seed germination $(\%)$, germination time, time to early blossoming, fruits number per plant, fruit diameter $(\mathrm{cm})$, fruit length $(\mathrm{cm})$, number of branches plant ${ }^{-1}$, vine length $(\mathrm{cm})$, fruit weight $(\mathrm{g})$, fruits yield plot $^{-1}(\mathrm{~kg})$, fruits yield $\left(\mathrm{t} \mathrm{ha} \mathrm{a}^{-1}\right)$, and cost-benefit ratio.

\section{Days to germination}

Analysis of variance (Fig. 1) shows nonsignificant differences for days to germination for layout methods varieties and their interaction. The non-significant variations and days have taken to germinate seed may be due to similar soil growing condition and the exact date of seed sowing; the same findings were reported by [20], who assessed the mobilization of antioxidant enzymes, subordinate to each of the oxidized seeds in the seed to retain the early emergence. 


\section{Seed germination $(\%)$}

The mean values of experimental results (Fig. 2) show non-significant seed germination (\%) for various layout and interaction methods. The non-significant seed germination percentage may increase due to seed soaking the same seed, sowing similar soil growing conditions. A better percentage of germination is triggered because it enhances the seeds sequence of metabolic activities necessary to initiate the sprouting actions, such as decomposition of dormancy, hydrolysis, growth inhibitor metabolism, absorption, and enzyme activation [20-22].

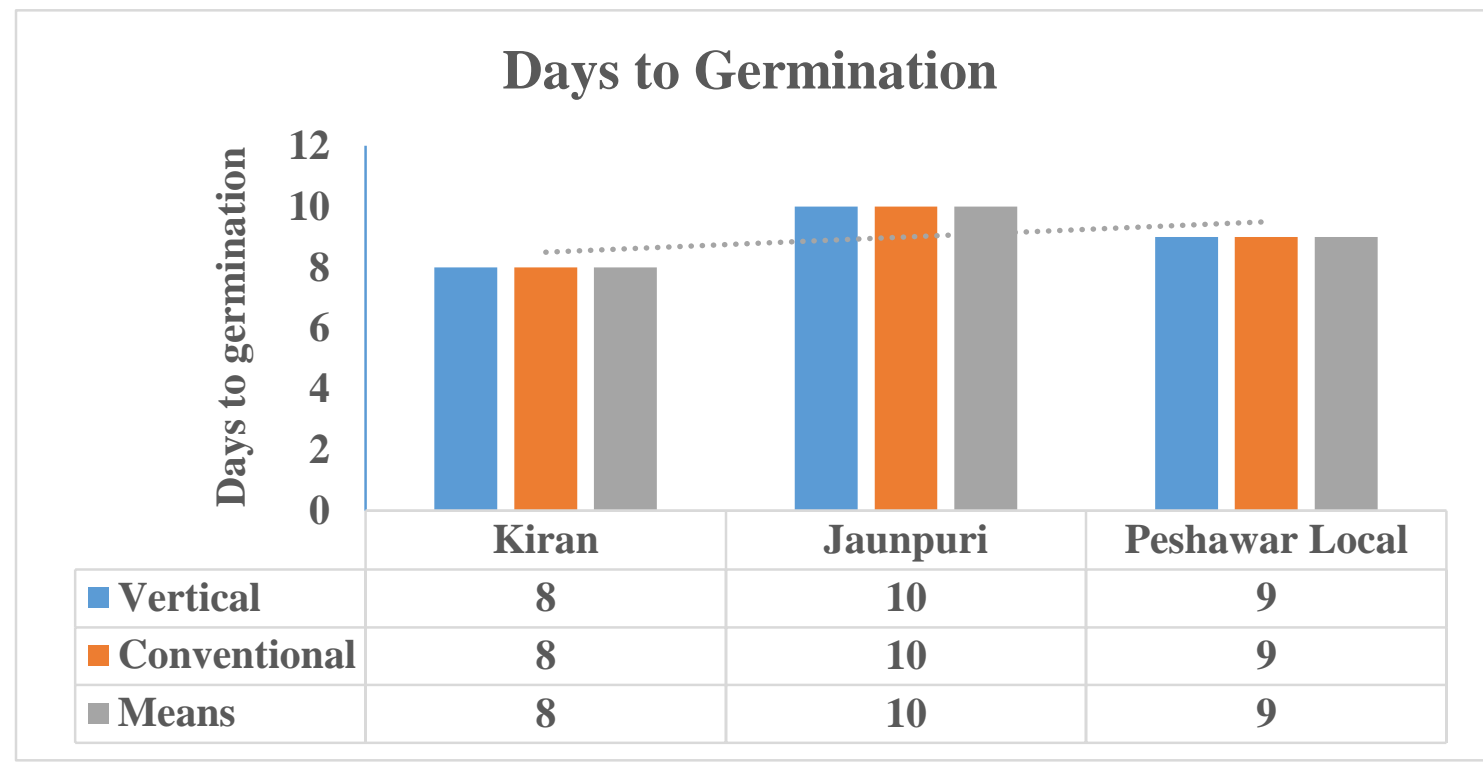

Figure 1. Days to germination of bitter gourd varieties as affected by different methods of field layout

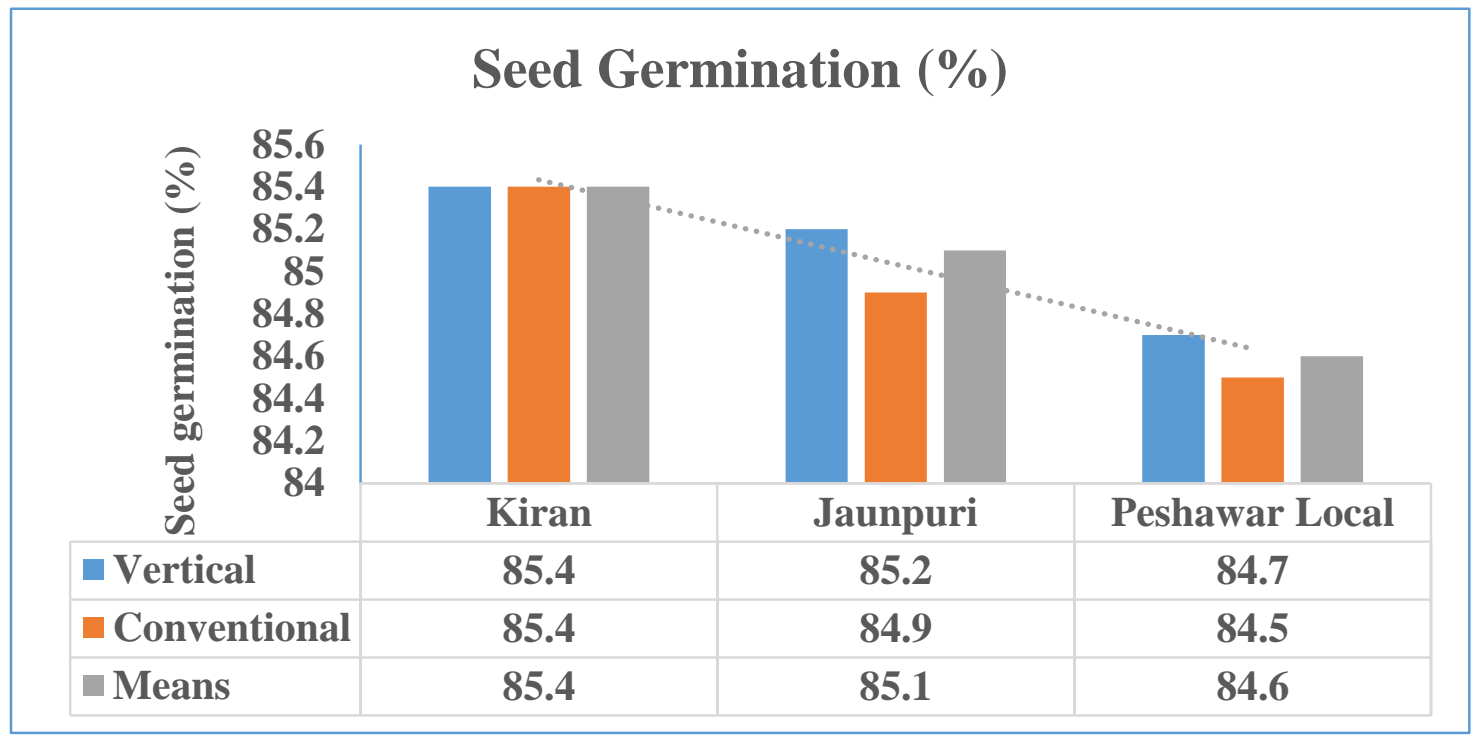

Figure 2. Seed germination (\%) of bitter gourd varieties as affected by different methods of field layout 
Days to flowering

Analysis of variance given in (Fig. 3) revealed significant differences among layout methods, varieties, and interaction. Maximum days to flowering (41days) were taken in a conventional layout method, while vertically trained plants in the net took minimum days flowering (39 days). Similarly, the maximum number of days until flowering (40) were taken by Peshawar Local while Jaunpuri, Kiran took minimum days to flower (39), and Peshawar Local variety is grown on the ground/conventional method took (42) days to start flowers. However, Kiran, Jaunpuri, and Peshawar Local took minimum days to flower $(38,39$, and 39 days) and were trained vertically on the net.
When vines were trained vertically on the net started earlier flowers due to vertical trailing, the vines became more efficient by receiving more sunlight, thereby increasing the plants' photosynthetic ability necessary for photosynthetic products plays a vital role in vines growth as well flower development. These results are related to [23] findings, stated that sunlight increases the quantity and quality of the flowers. Similarly, genetic variability is also a crucial factor in determining the days to germination of the varieties. Similarly, [24] reported the effect of many trailing methods and observed more number of flowers per vine, branches per vine, vine length, fruit weight, and total yield.



Figure 3. Days to the flowering of bitter gourd varieties as affected by different methods of field layout

\section{Number of fruits vine -1 $^{-1}$}

The number of fruits vine ${ }^{-1}$ were shown in the variance analysis (Fig. 4) revealed significant results for varieties and layout methods but non-significant for their interaction. The maximum number of fruits vine ${ }^{-1}$ (18.2) was observed in vines trained vertically on the net. In varieties, the higher number of fruits vine $^{-1}$ (17.6) were studied in variety Kiran, whereas the minimum number of fruits vine ${ }^{-}$

1 (14.5) were obtained by variety Peshawar Local because the interaction was not significant. The number of fruits $v^{-1} \mathrm{e}^{-1}$ showed maximum yield on the net vertically trained vine, which may be because the maximum number of flowers can set more fruits; moreover, the higher yield in vertical trained vines on the net was more exposed to 
sunlight and even distribution of photosynthetic from source (leaves) to other parts of the vine mainly fruits, which the central part of the vine. Similar findings were revealed by $[24,25]$ in ridge gourd and [26] in cucumber and showed that increasing fruits vine ${ }^{-1}$ in the vertical trailing method directly affected yield attributes. All attributes help in fruit setting and translocation of more photosynthates from leaves to different plants via the phloem.

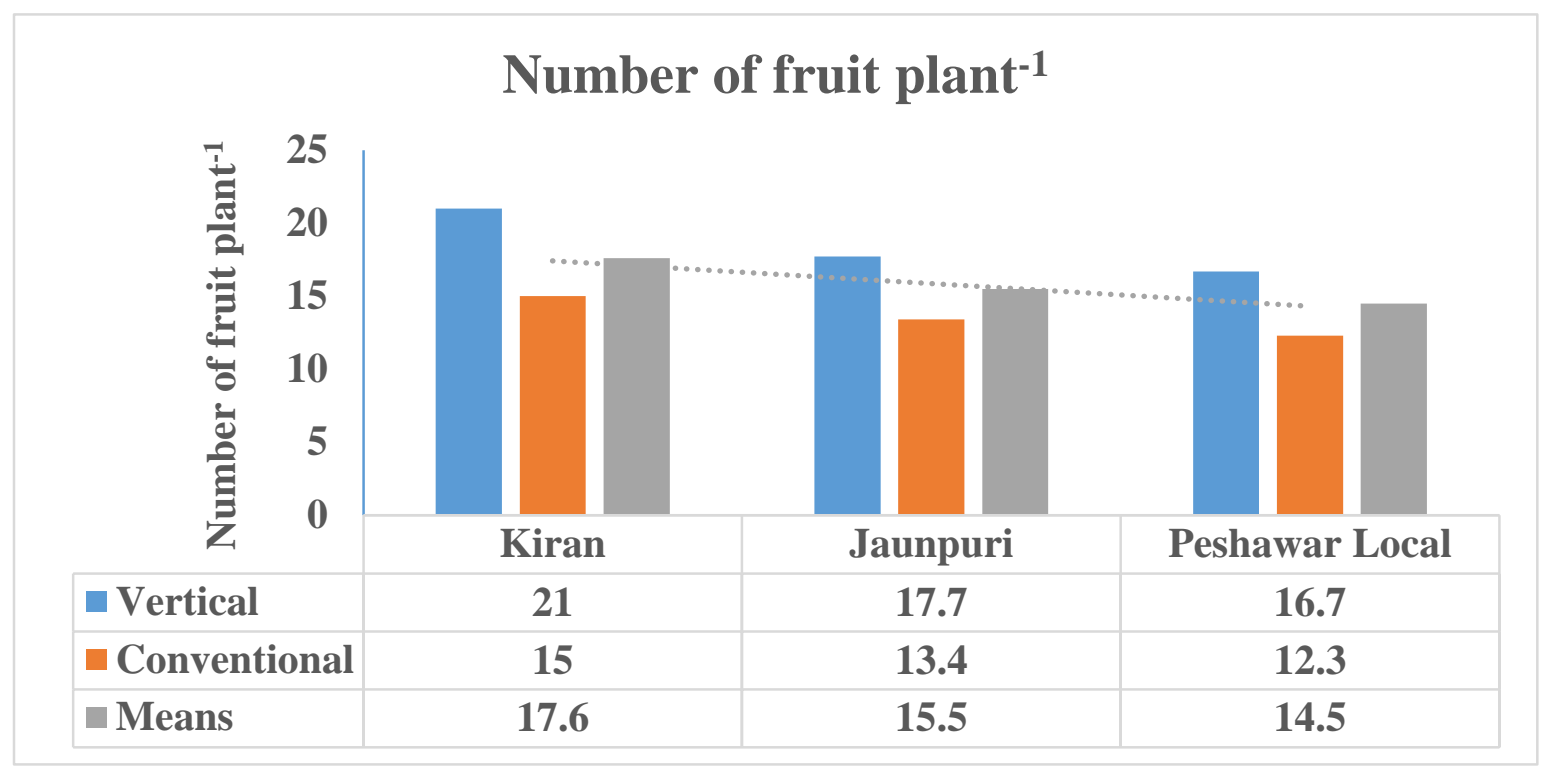

Figure 4. Number of fruit plant ${ }^{-1}$ of bitter gourd varieties as affected by different methods of field layout

\section{Fruit length (cm)}

Fruit length showed significant differences for layout methods and varieties (Fig. 5). While and their interaction had no significant effect between methods and varieties.

The higher fruit length $(17.44 \mathrm{~cm})$ was achieved when the plant vertically trained on the net. In varieties, the higher fruit length $(19.18 \mathrm{~cm})$ was found in the Kiran variety, while the minimum fruit length $(15.64 \mathrm{~cm})$ was founded in Peshawar Local variety, and their interaction was non-significant. Fruit length was affected by vertical trailing on the net method, probably due to good utilization of sunlight. A similar result was found that the changes may because of irregular interception of light in various types of trailing methods that affect the fruit length. A higher number of fruit lengths were observed in the Kiran variety, the inherited character of the variety $[25,27]$ in teasel gourd and better gourd respectively and [26].

\section{Fruit diameter $(\mathbf{c m})$}

Data regarding fruit diameter $(\mathrm{cm})$ are shown in (Fig. 6) showed that the interaction between methods and varieties was significant. While cultivation methods, varieties had a significant effect on fruit diameter. The highest fruit diameter $(4.82 \mathrm{~cm})$ was obtained by vines trained vertically on the net. The maximum number of fruits diameter $(5.25 \mathrm{~cm})$ was recorded in variety Kiran, while minimum fruits diameter $(4.15 \mathrm{~cm})$ was obtained in variety Peshawar Local. The increasing fruit diameter on net vertically trained plants. It may be due to more photosynthesis from the source (leaves) to these components (Sink). These results are similar to [24] in the gourd, [27] the effect of the trellis, [25] in ridge gourd, and [26] in 
cucumber. The number of fruits vine $^{-1}$ studied was higher in the telephone method of trailing increased yield parameters, fruit set, and translocation from the light source to sink more photosynthesis.

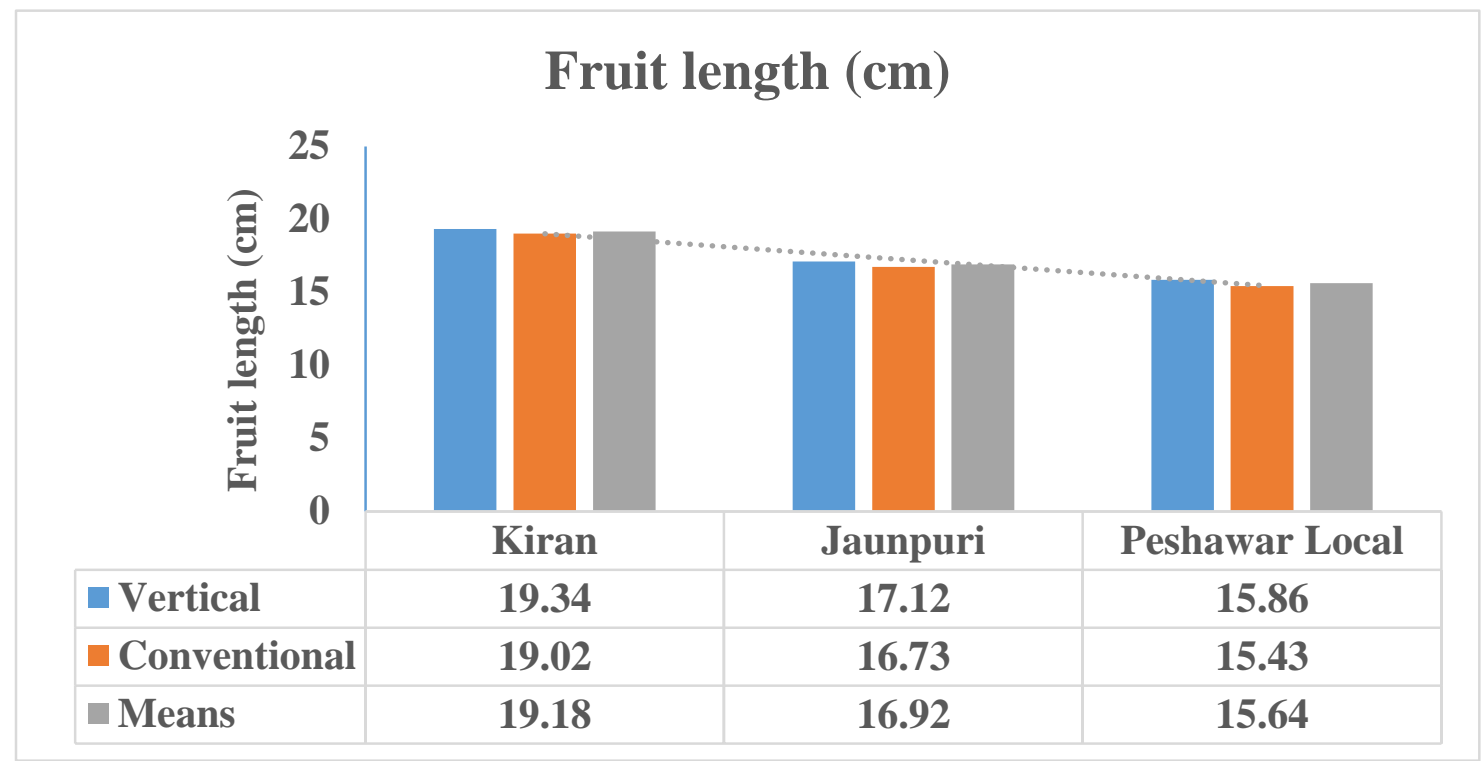

Figure 5. Fruit length $(\mathrm{cm})$ of bitter gourd varieties as affected by different methods of field layout

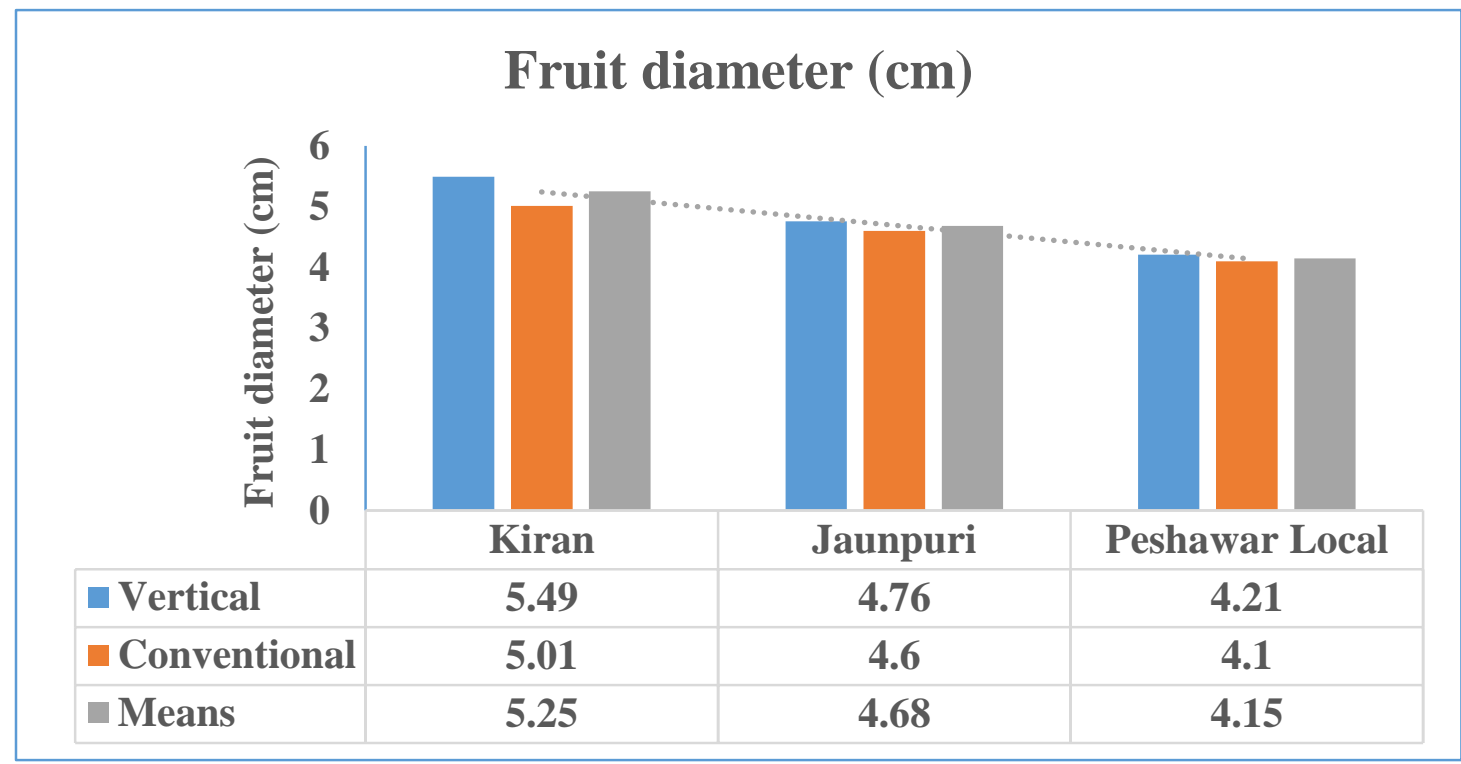

Figure 6. Fruit diameter $(\mathrm{cm})$ of bitter gourd varieties as an effect by different methods of field layout

Vine length (m)

According to the mean of vines length, the trailing method and variety were significantly affected, while their interaction had no significant effect between varieties, trailing methods. The maximum vine length $(4.42 \mathrm{~m})$ was recorded when the plants were trained vertically on the net; the minimum length of 
the vine $(4.40 \mathrm{~m})$ was shown in the conventional method. Kiran varieties observed the highest vine length $(4.45 \mathrm{~m})$, and Peshawar local variety had the lowest vine length (4.38m) (Fig. 7). When plants were trained, they are exposed to more sunlight on the net, which increases the photosynthesis and assimilation of increased carbohydrate length of carbohydrates. Our findings matched those of $[25,28]$ in the gourd and sponge, [29] in the melon. Similarly, another result was found of the trailing method of growing and traditional method, and the trailing method shows a significantly higher vine $^{-1}$ length. They also reported that the tailing method provided more sunshine for plant growth. The higher vines were recorded on the variety Kiran which probably attributed to their genetic background, resulting in vine length [18].

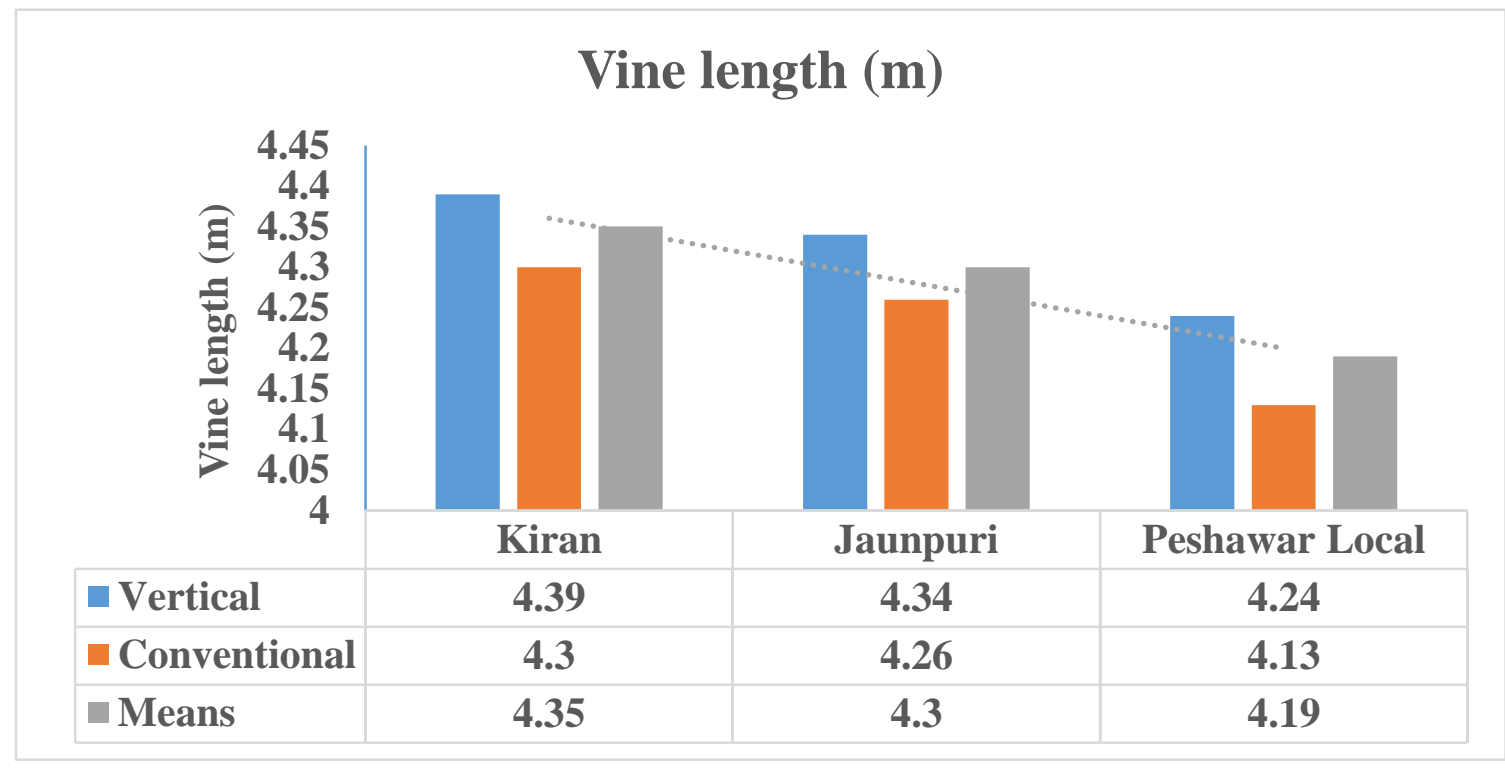

Figure 7. Vine length (m)of bitter gourd varieties as affected by different methods of field layout

\section{Number of branches vine ${ }^{-1}$}

Statistical analysis presented that various trailing ways and varieties had significantly affected. The number of branches Vine ${ }^{-1}$ and the interaction between the trailing method and the variety had no significant affected. The maximum number of branches vine $^{-1}$ (9.47) was founded when plants vertically trained on the net. Kiran variety recorded a higher number of branches vine ${ }^{-1}$ (9.66) as compared to Jaunpuri and Peshawar Local, which had (9.11) and (8.82) number of branches vine ${ }^{-1}$ respectively (Fig. 8).
Vine vertical training on the net was superior because more sunlight penetrated the plant canopy, due to which the rate of photosynthesis increases and the plants yield and more branches. Our findings follow the findings of $[28,30]$ in the gourd and [29] in melon, which reports the trailing method to increase photosynthesis and photosynthesis assimilation to increase plant growth. Similarly, [31] observed a significant increase in vegetative growth, flowering, number of branches, and yield components, including; seed length and width in the vertical layout method. 


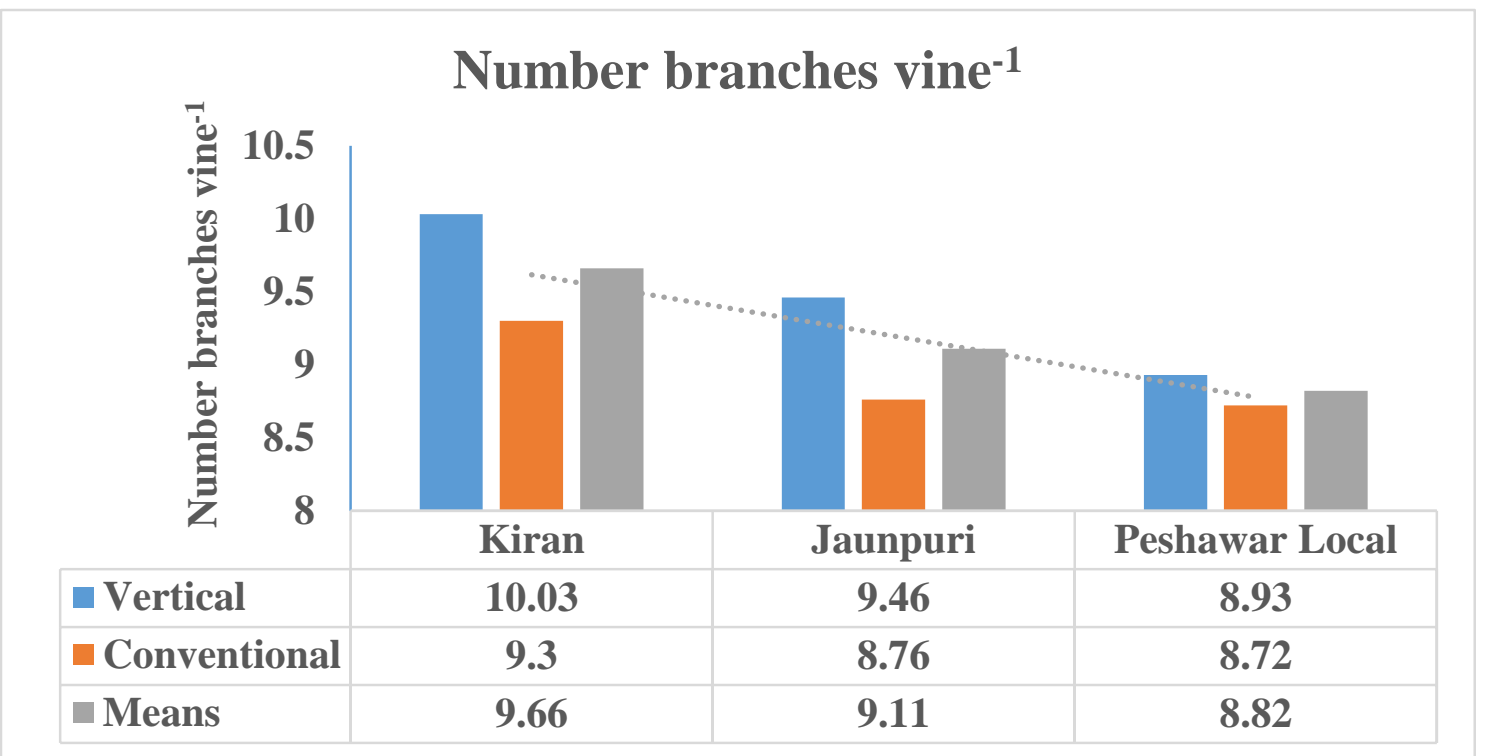

Figure 8. Number branches vine ${ }^{-1}$ of bitter gourd varieties as affected by different methods of field layout

\section{Weight of fruits}

Findings related to the weight of fruits in grams given in (Fig. 9) and ANOVA confirmed no effect on fruit weight by the interaction between layout methods and varieties and fruit weight significantly impacting varieties and layout method. The highest fruit weight $(67.25 \mathrm{~g})$ was gained by fruit when the net vines were trained vertically. In varieties, Kiran reported that the highest fruit weight $(68.02 \mathrm{~g})$, and variety Peshawar Local reported the lowest fruit weight $(63.83 \mathrm{~g})$.

Plant trained vertically has more mass of fruits, more branches, and vine length, and these findings matched with the findings of [25] in the gourd, [26] reported in the bitter gourd of cucumber, and [30] that high yield in tailing methods is due the transfer of more dry matter in the leaf to the sink. Similarly, [32] reported more branches $v^{-1} e^{-1}$, vine length, fruit weight, and total yield with the vertical method.

\section{Fruit yield plot $^{-1}(\mathbf{k g})$}

Analysis of variance revealed significant results for varieties, layout methods where their interaction (varieties $\times$ layout method) exhibited non-significant results (Fig. 10). Maximum fruit yield plot $^{-1}(12.27 \mathrm{~kg})$ was found in the vertical method, while the minimum was noted in the conventional method $(8.76 \mathrm{~kg})$. Whereas varieties Kiran showed maximum yield. (12.01 kg) Furthermore, the low yield was noted in Peshawar local. In vertically trailing vines, the production was superior. This may be due to early flowering, more fruit length, and the number of branches vine ${ }^{-1}$ and many fruits shown on the plants, which improved the yield. These results are similar to [33] in melon, [30] in bitter gourd. Another result was found in vertical cucumber methods, which significantly increased the growth and yield. Kiran variety studied the high yield as compared to other variety. This may be a genetic feature of Kiran, which makes it superior in the gourd [24]. 




Figure 9. Fruit weight (g) of bitter gourd varieties is affected by different methods of field layout

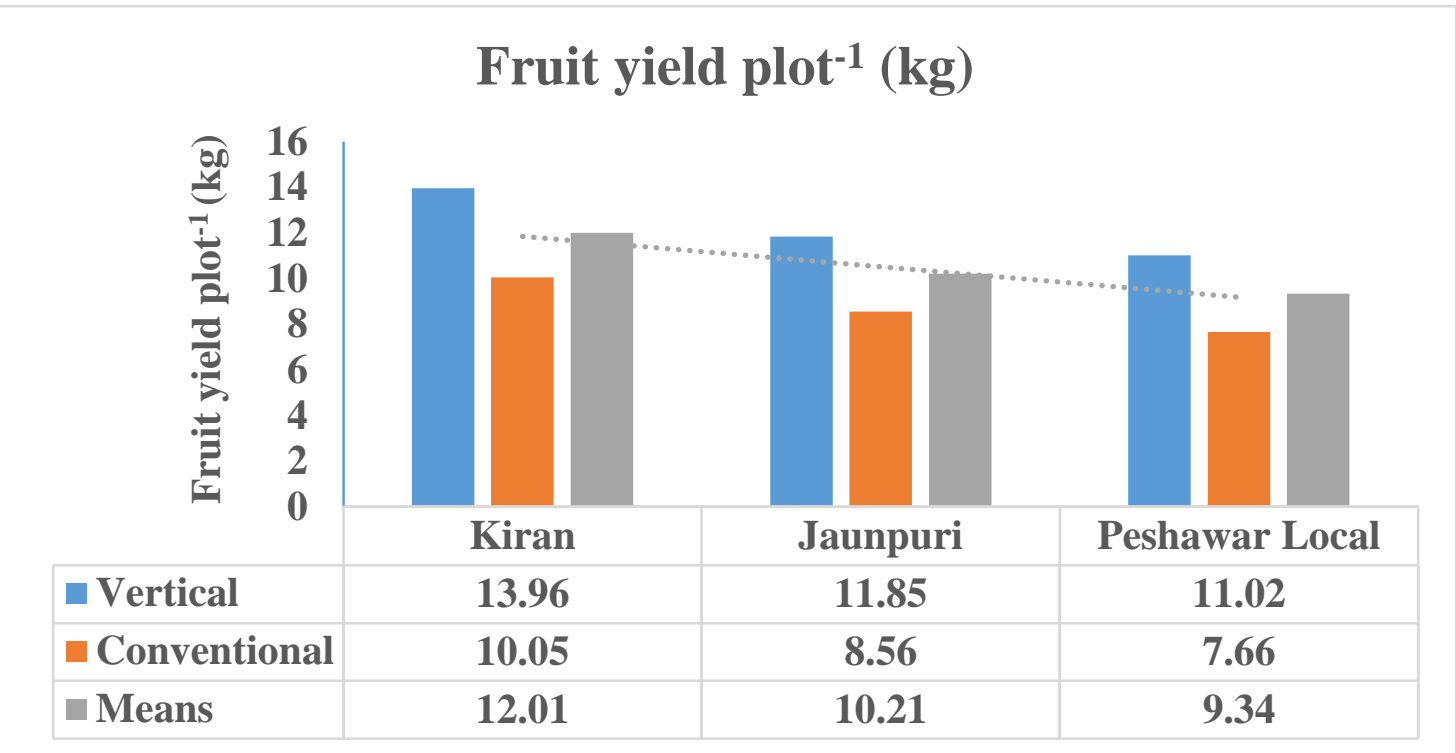

Figure 10. Fruit yield plot $^{-1}(\mathrm{~kg})$ of bitter gourd varieties as affected by different methods of field layout

\section{Fruit yield (t ha-1)}

The data studied on fruit yield $\left(\mathrm{t} \mathrm{ha}^{-1}\right)$ are presented in (Fig. 11). The statistical analysis showed that different methods layout and varieties had a significant effect on the fruit yield $\left(\mathrm{t} \mathrm{ha}^{-1}\right)$, and the interaction between the layout methods and the varieties had no significant effect on the total yield $\left(\mathrm{t} \mathrm{ha}^{-1}\right)$.
The higher yield (13.63 t ha-1) was recorded when plant vines vertically trained on the net, while the minimum yield (9.73 t ha-1) was founded when the vine was grown conventionally on the ground. Kiran showed the maximum yield (13.34 $\mathrm{t}$ ha-1), and Peshawar Local showed a low yield (10.38 t ha-1). In the vertically backward vines, the 
yield is high, which may be due to early flowering, fruit length is longer, and the vine has more branches on the vine ${ }^{-1}$ and more fruit, thus increasing the yield. These results are similar to those of [33] in watermelon, $[24,32]$ in the gourd. Another result found in the vertical method significantly increased growth and yield. Compared with other breeds, Kiran varieties showed high yields; this may be a genetic feature of Kiran, which makes it superior [25] in the gourd and cucumber [26].

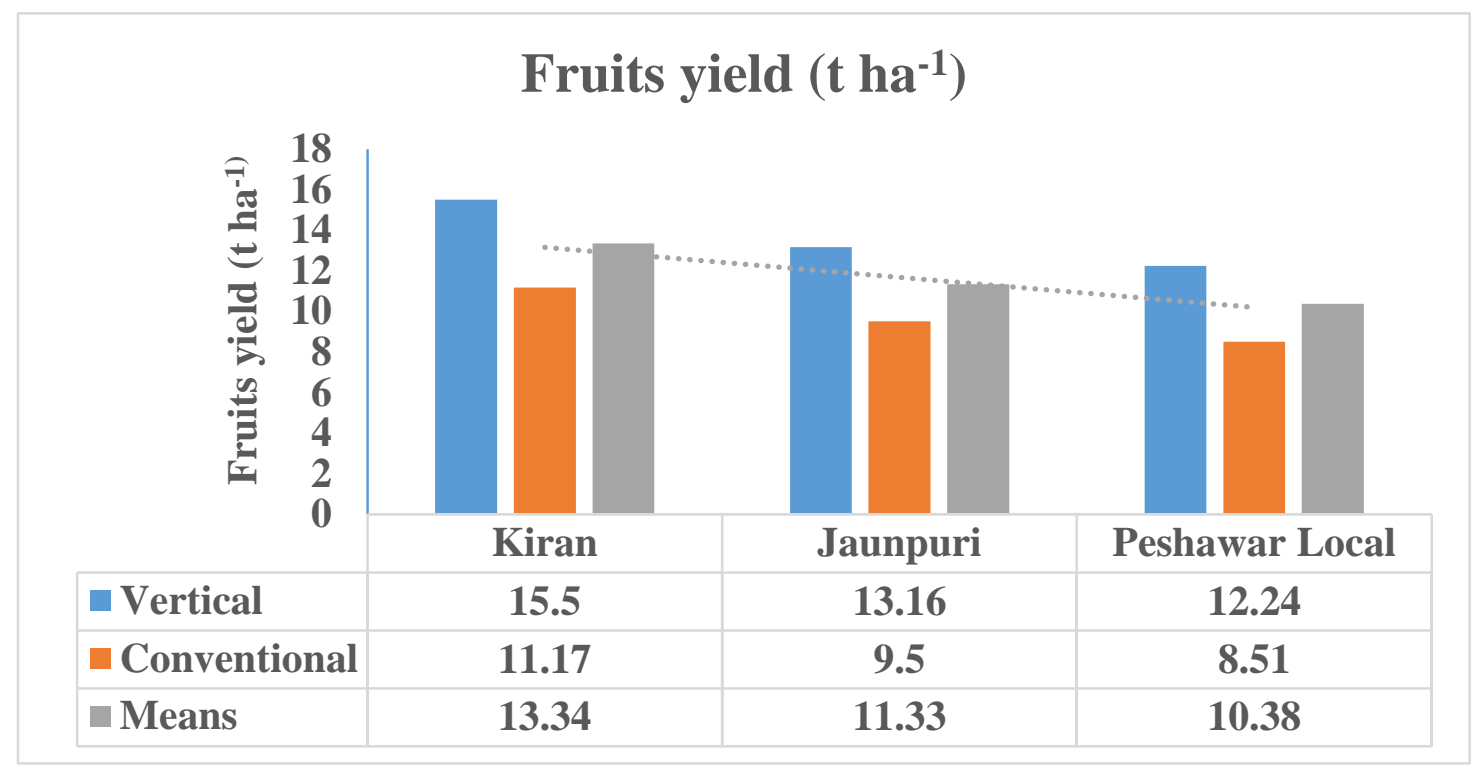

Figure 11. Fruits yield ( $\left(\mathrm{ha}^{-1}\right)$ of bitter gourd varieties as affected by different methods of field layout

\section{Cost-Benefit Ratio}

The Cost-Benefit Ratio data were pertaining in (Table 2). The input cost for land preparation, fertilizer, seed cost, manure cost, and power required for all the operations to transplant seedlings to the harvesting of bitter gourd was recorded for the unit of cost per hectare. Prices of bitter gourd were considered in the market rate basis of the Peshawar market.
Vertical and Conventional methods showed different results. The highest Net return (Rs. 153143.34) was obtained from the Vertical layout method compared to the Conventional method. CBR was (7.69) for the vertical method of layout. Imran [34] reported that the highest net return is high yield $\mathrm{tha}^{-1}$ in the vertical method.

Table 2. The cost-benefit ratio of better gourd varieties is affected by various cultivation methods

\begin{tabular}{|c|c|c|c|c|c|c|}
\hline $\begin{array}{c}\text { Layout } \\
\text { Methods }\end{array}$ & $\begin{array}{c}\text { Fruits } \\
\text { yield } \\
\left(\text { kg ha-1) }^{-1}\right.\end{array}$ & $\begin{array}{c}\text { yields } \\
\text { values in Rs }\end{array}$ & $\begin{array}{c}\text { Additional } \\
\text { income } \\
\text { vertical } \\
\text { method }\end{array}$ & $\begin{array}{c}\text { Additional } \\
\text { cost } \\
\text { cultivation } \\
\text { methods }\end{array}$ & $\begin{array}{c}\text { Net profit } \\
\text { vertical } \\
\text { method }\end{array}$ & CBR \\
\hline Vertical & 15144.44 & 787511.11 & 225333.34 & 72190 & 153143.34 & 7.69 \\
\hline Conventional & 10811.11 & 562177.77 & & 42890 & & \\
\hline
\end{tabular}

Bitter gourd per kg = Rs. 52

Net Price per plot $=$ Rs. 20 


\section{Conclusion and Recommendations}

It was concluded that more flowers, excellent fruit, vine length, and high yield had been obtained at net trailing in the vertical position. The production outputs, including fruit length and fruit numbers of Kiran variety, had a maximum overall experiment. However, the relation between layout methods and varieties was not significantly affected by most studied parameters, except days to flowering. Furthermore, a costbenefit ratio of 7.69 was observed for vertical layout methods. Based on the above conclusion following recommendations can be drawn from the research. Growth and quality in the vertical method are best than all other methods, and it can ensure a higher cost-benefit ratio than the other methods. Among the varieties, Kiran variety was comparatively superior in yield and quality for bitter gourd under Peshawar valleys agroclimatic conditions.

\section{Authors' contributions}

Conceived and designed the experiments: A Khan, Performed the Experiments: A Khan, Analyzed the Data: Q Hussain, M Asim \& N Khan, Contributed reagents/ materials/ analysis tools: A Khan, R Ullah, M Ali, M Khan \& A Naeem, Wrote the paper: A Khan \& Q Hussain.

\section{References}

1. Baloch AF (1994). Vegetable Crops: Hort. Nat. Book Found. Islam. pp. 529531.

2. Raychaundhurdy A, Mitra SK \& Bose TK (1982). Studies on the nutrition of ridge gourd. Punjab Hort J 22(3):185-189.

3. Chang YM, Cheng YH, Hsu WS \& Huang PL (2000). Observation of fruit anatomy and development of bitter gourd: II. Development of embryo, seed and fruit of bitter gourd. J. Agri. Res. China. 49(2): 4960.

4. Konsler TR \& Strides DL (1973). The response of cucumber to trellis vs. ground culture. Hort. Sci. 8: 320-321.
5. Hanna HY, Adams AJ, \& Story RN (1987). Increased yield in sliciy cucumber with vertical training of plants and reduced plants spacing. Hort Sci 22(1): 32-34.

6. Tindall HD (1983). Vegetables in the tropics. Eng.Lang. Book Soc. Macmillan, Hong Kong. pp. 190-191.

7. Welihinda J, Karananayake EH, Sheriff MH \& Jayasinghe KS (1986). Effect of (Momodica charantia) on the glucose tolerance in maturity onset diabetes. $J$ Ethnopharm 17: 277-282.

8. Raman A \& Lau C (1996). Anti-diabetic properties and photochemistry of momodicacharantia L. (cucurbitaceous). Phytomed 2: 349-362.

9. Gurbuz I, Akyuz C, Yesilada \& Bilge S (2000). Anti-ulcerorganic effect of momodicacharantia L. fruits on various ulcer models in rats. J Ethnopharm. 71: 7782.

10. Scartezzini P \& Speroni E (2000). Review on some plants of Indian traditional medicine with antioxidant activity. $J$ Ethnopharm 71: 23-43.

11. Belon N, Gbeassor M, Akpagana K, Hudson J, Soussa K, Koumaglo K \& Arnoson JT (2005). Ethnomedicinal uses of momodicacharantia in Togo and relation to its photochemistry and biological activity. J Ethnopharam 96: 49-55.

12. Subratty AH, Fakim AG \& Mahomoodally F (2005). Bitter melon, an exotic vegetable with medicinal values. Nutr Food Sci 35: 143-147.

13. Behera TK, Staub JE, Behere S \& Simon PW (2008). Bitter gourd and human health. Med Arom, Plant Sci Biol 1: 224-226.

14. Peter KV, Sadhu MK, Raj M \& Prasanna KP (1998). Improvement and cultivation bitter gourd snak gourd and pointed gourd. Sci Pub 187-195.

15. Lin JM \& Sung JM (2001). Pre-sowing treatment for improving emergence of bitter gourd seedling under optimal and sub-optimal temperature. Seed Sci Technol 29: 39-50.

16. Hsu CC, Chen CL, Chen JJ \& Sung JM (2003). Accelerated aging-enhanced lipid 
per oxidation in better gourd seed and effect of priming and hot water soaking treatment. Sci Hort 98: 201-212.

17. MNFSR (2015). Fruit, vegetables, and condiments statistics of Pakistan. Govt. of Pak. Ministry of national food security and research (Economic Wing) Islamabad. (http://www.mnfsr.gov.pk/pubDetails.aspx ) pp. 11-18.

18. Sharma RK, Tomar BS, Singh SP \& Kumar A (2016). Effect of growing methods on seed yield and quality in bottle gourd (Lagenariasiceraria). Indian J of Agri Sci 86(3): 373-378.

19. Steel RGD, Torrie JH \& Dickey DA (1980). Principles and Procedures of statistics. A biometrical approach, $3^{\text {rd }} E d$. McGraw Hill Book Co Inc New York, pp.172-177.

20. Farooq M, Basra SMA, Hafeez K, Asad SA \& Ahmad N (2009). Use of commercial fertilizers as osmotic for rice priming. $J$ Agric and Social Sci 1: 172-175.

21. Ajouri A, Asgedom A \& Becker M (2004). Seed priming enhances germination and seedling growth of barley under conditions of $\mathrm{P}$ and $\mathrm{Zn}$ deficiency. J Pl Nutri Soil Sci 16(2): 630-636.

22. Pukacka, S. andE. Ratajczak. 2005. Production and scavenging of reactive oxygen species in Fagus sylvatica seeds during storage at varied temperature and humidity. J Plant Physiol 162: 873-885.

23. Thomas B (2006). Light signal and flowering. $J$ Exp Bot 57(13): 3387-3393.

24. Hilli JS \& Vyakarnahal BS, Biradar DP \& Hunje R (2009). Influence of method of trailing and fertilizer levels on seed yield of ridge gourd. Karna J Agric Sci 22(1): 4752.

25. Yadav JP, Singh K \& Jaiswal RC (1989). Influence of various spacing and Methods trailing on growth and yield of pointed gourd (Trichosanthes Dioica Roxb.). Veget Sci 16(2): 113-118.

26. Ravikumar GH (2000). Investigations on seed production and post-harvest techniques in cucumber (Cucumissativus L.) cv. Poinsett. Ph. D. Thesis, Uni. Agri. Sci. Dharwad.

27. Mian AY, Rahman MM, Mian MAK, Hossain MM, Islam MS \& ShahidulIslam M (2001). Performance of teasel gourd genotypes grown on different trellis. Bangla J Biol Sci 1(5): 369-371.

28. Saimbhi MS (1993). Agro techniques for cucurbits. Adv Hort 5(1): 401-431.

29. Patil VK, Gupta PK \& Tamber PG (1993). Influence of pruning, mulching and nitrogenous fertilizer on growth, yield and quality of stacked plants of Sioux variety of tomato. Punj Vege Grow 8: 4-9.

30. Shantappa T (2004). Seed technological investigation in bitter gourd (Momodicacharantia Linn.). Ph. D. Thesis, Uni Agric Sci Dharwad.

31. Sure S, Arooie H \& Azizi M (2012). Influence of plant growth regulator and planting method on growth and yield in oil pumpkin. Deptt. Hort Sci Mushhad, Iran Not Sci Biol 4(2): 101-107.

32. Hilli JS \& Vyakarnahal BS, Biradar DP \& Hunje R (2009). Influence of method of trailing and fertilizer levels on seed yield of ridgegourd (Luffa acutangula L. Roxb). Karnataka J Agric Sci 22(1): 47-52.

33. Singh B, Mangal JL \& ML Pandita ((1982). Effect of pruning, spacing and fertilizer levels on flowering, fruiting. Yield and quality of muskmelon. Haryana. Agric Uni J Res 12: 64-68.

34. Imran MD (2018). Morphological and yield attributes of brinjal (Solanum melongena L.) varieties in response to gibbellic acid. World J Agric Sci 14 (2): 5661 . 